\title{
Grewioideae Dippel (Malvaceae) no Estado da Paraíba, Brasil ${ }^{1}$
}

\author{
- $\underline{\text { Stefanny Martins de Souza }}^{2}$, ${ }^{\text {Fernanda Kalina da Silva Monteiro }}{ }^{3}$ e osé Iranildo Miranda de Melo $^{2,4}$
}

Recebido: 13 fevereiro 2019; aceito: 28 novembro 2019

Como citar: Souza, S.M., Monteiro, F.K.S. \& Melo, J.I.M. 2020. Grewioideae Dippel (Malvaceae) no Estado da Paraíba, Brasil. Hoehnea 47: e122019. http://dx.doi.org/10.1590/2236-8906-12/2019.

ABSTRACT - (Grewioideae Dippel (Malvaceae) in the state of Paraíba, Brazil). Malvaceae Juss. is included in the Malvales order and presents a cosmopolitan distribution. It comprises approximately 4,300 species allocated into 243 genera. The family is subdivided into nine subfamilies, amongst them Grewioideae with approximately 25 genera and 700 species associated to the tropical regions. In Brazil, this subfamily is represented by ten genera and about 60 species. The present work comprises the taxonomic survey of Grewioideae in the Paraíba State. Consultations were made to digitized databases as well as visits to physical herbaria, collecting expeditions and 'in loco' observations. Seven species from four genera were recorded in the study area: Apeiba tibourbou Aubl., Corchorus argutus Kunth, C. hirtus L., Luehea ochrophylla Mart., $L$. paniculata Mart., Triumfetta rhomboidea Jacq., and T. semitriloba Jacq.. The species Corchorus argutus is a new occurrence for the Paraíba State, occurring in an area of Caatinga.

Keywords: brazilian northeastern, diversity, Malvales, taxonomy

RESUMO - (Grewioideae Dippel (Malvaceae) no Estado da Paraíba, Brasil). Malvaceae Juss., enquadrada na ordem Malvales, é uma família de distribuição cosmopolita. Compreende aproximadamente 4.300 espécies alocadas em 243 gêneros. Está subdividida em nove subfamílias, dentre elas Grewioideae, que reúne aproximadamente 25 gêneros e 700 espécies associadas às regiões tropicais. No Brasil, essa subfamília encontra-se representada por nove gêneros e aproximadamente 60 espécies. Este trabalho compreende o levantamento taxonômico de Grewioideae no Estado da Paraíba. Foram realizadas consultas em bases digitalizadas, visitas a herbários físicos e excursões para coletas e observações 'in loco'. Na área de estudo, foram registradas sete espécies em quatro gêneros: Apeiba tibourbou Aubl., Corchorus argutus Kunth, C. hirtus L., Luehea ochrophylla Mart., L. paniculata Mart., Triumfetta rhomboidea Jacq. e T. semitriloba Jacq.. Corchorus argutus compreende uma nova ocorrência para o Estado da Paraíba, sendo encontrada exclusivamente em área de Caatinga. Porém, o domínio de Mata Atlântica apresentou maior riqueza no Estado, sendo todas as demais espécies observadas no mesmo, enquanto apenas três foram registradas na Caatinga.

Palavras-chave: nordeste brasileiro, diversidade, Malvales, taxonomia

\section{Introdução}

Malvaceae Juss. apresenta distribuição cosmopolita, compreendendo aproximadamente 4.300 espécies alocadas em 243 gêneros (Bayer \& Kubitzki 2003) e nove subfamílias: Bombacoideae Burnett, Browlowioideae Burnett, Byttnerioideae Burnett, Dombeyoideae Beilschm., Grewioideae Dippel., Helicterioideae (Schott \& Endl.) Meisn., Malvoideae Burnett, Sterculioideae Burnett e Tilioideae Arn. (Alverson et al. 1999, Bayer et al. 1999, Brunken \&
Muellner 2012, Nyffeler et al. 2005, Simpson 2006, APG IV 2016). No Brasil, está representada por 781 espécies em 72 gêneros, 412 destas endêmicas. Seus representantes distribuem-se em todas as regiões e domínios fitogeográficos brasileiros, inclusive na Ilha oceânica de Fernando de Noronha (Flora do Brasil 2020). A subfamília de maior representação no Brasil é Malvoideae (também considerada o maior grupo de Malvaceae), sendo Pavonia Cav. e Sida L. os gêneros mais diversos, com 142 e 103 espécies respectivamente (Grings 2011, Flora do

1. Parte do Trabalho de Conclusão de Curso da primeira Autora

2. Universidade Estadual da Paraíba, Centro de Ciências Biológicas e da Saúde, Departamento de Ciências Biológicas, R. Baraúnas, 351, Bairro Universitário, 58429-500 Campina Grande, Paraíba, Brasil

3. Universidade Federal Rural de Pernambuco, Departamento de Biologia, Área de Botânica, Rua Dom Manuel de Medeiros, s/n, Dois Irmãos, 52171-900 Recife, Pernambuco, Brasil

4. Autor para correspondência: tournefort@gmail.com 
Brasil 2020). Reúne plantas herbáceas a arbóreas, sendo caracterizadas principalmente pela presença de um nectário formado de tricomas glandulares, localizado internamente na base do cálice ou com menos frequência, nas pétalas ou no androginóforo (Judd \& Manchester 1997, Bayer et al. 1999).

Grewioideae Dippel inclui a maioria dos gêneros da previamente inclusos na tradicional família Tiliaceae (sensu Cronquist 1981). Compreende aproximadamente 30 gêneros e 700 espécies distribuídas em regiões tropicais (Bayer \& Kubitzki 2003). No Brasil, está representada por nove gêneros (Apeiba Aubl., Corchorus L., Heliocarpus L., Hydrogaster Kuhlm., Luehea Willd., Lueheopsis Burret, Mollia Mart., Triumfetta L. e Vasivaea Baill.) e 56 espécies associadas aos domínios fitogeográficos da Amazônia, Caatinga, Cerrado, Mata Atlântica e Pantanal (Flora do Brasil 2020), sendo Mollia o gênero mais diversificado no país, com 14 espécies. Para a região Nordeste há registros de 47 espécies distribuídas em seis gêneros.

Asubfamília reúne de ervas a árvores, apresentando indumento comumente recoberto pro tricomas, que podem ser simples ou estrelados. Possuem folhas simples, frequentemente com tricomas secretores associados. As flores podem apresentar-se solitárias ou reunidas em inflorescências cimosas, normalmente diclamídeas, com numerosos estames e gineceu pluricarpelar. Os frutos podem ser baga, cápsula ou esquizocarpo, muitas vezes recobertos por espinhos ou cerdas (Bayer \& Kubitzki 2003).

Várias das espécies de Grewioideae apresentam potencial econômico, sendo utilizadas para fins artesanais, ornamentais e medicinais, entre outros. Espécies do gênero Apeiba Aubl., por exemplo, têm sua madeira largamente empregada na construção de jangadas devido a sua flutuabilidade, suas fibras são empregadas na produção de cordas, além de utilizada para fins medicinais, sendo empregada popularmente como antirreumática, antiespasmódica, estimulante estomacal, anti-inflamatória e para afecções respiratórias (Corrêa 1985, Heywood 1978, Lasure et al. 1994); espécies de Corchorus L. e Triumfetta L. destacam-se como fornecedoras de fibras; algumas do gênero Luehea Willd. fornecem madeira para a carpintaria, além de serem utilizadas na medicina popular como antitérmicas, antiespasmódicas e anti-inflamatórias (Araújo et al. 2007, Corrêa 1985, Heywood 1978).

Estudos taxonômicos acerca da subfamília ainda são escassos no Brasil, podendo ser citados apenas estudos voltados para Tiliaceae que englobam gêneros hoje incluídos em Grewioideae (Esteves 2006, Azevedo \& Valente 2005, Souza \& Esteves 2002, Tschá et al. 2002), estudos de Malvaceae s.l. que também incluem gêneros de Grewioideae (Alves et al. 2011, Silva 2014) e outros que reportam novas espécies da subfamília para o país (Dorr 2012, Fernandes-Júnior et al. 2018).

Considerando a representatividade de Grewioideae no território brasileiro e paradoxalmente, a escassez de abordagens taxonômicas sobre a mesma aliadas à importância econômica apresentada pelo grupo, o presente trabalho teve como objetivo realizar o tratamento taxonômico da subfamília na Paraíba visando ampliar o conhecimento sobre a diversidade e distribuição geográfica da mesma no Estado e na região nordeste.

\section{Material e métodos}

Área de estudo - O Estado da Paraíba (06 00'11"S$08^{\circ} 19^{\prime} 54^{\prime \prime} \mathrm{W}$ e $34^{\circ} 45^{\prime} 50^{\prime \prime} \mathrm{S}-38^{\circ} 47^{\prime} 58^{\prime \prime} \mathrm{W}$ ) localiza-se na região Nordeste, limitando-se ao Norte, com o Estado do Rio Grande do Norte; ao Sul, com o Estado de Pernambuco; a Leste, com o Oceano Atlântico, em Ponta do Seixas; a Oeste, com o Estado do Ceará. Possui uma área de $56.469,46 \mathrm{~km}^{2}$ de extensão, abrangendo 223 municípios, e está dividido em quatro mesorregiões: a Mata, o Agreste, a Borborema e o Sertão (IDEME 2015). O clima é predominantemente quente, com temperatura média anual de $22^{\circ} \mathrm{C}$ à $26^{\circ} \mathrm{C}$ e precipitação média anual entre 800 e $1.600 \mathrm{~mm}$ (AESA 2006).

Engloba diferentes formações vegetacionais, sendo que aproximadamente $90 \%$ do seu território corresponde à vegetação de Caatinga, marcada por solos arenosos e flora arbustivo-arbórea, além de campos e matas de restinga, de solo arenoso e profundo e plantas com hábito arbustivo de densidade variável; mata úmida, com os tipos Floresta Perenifólia Costeira, denominada como Mata Atlântica, e Floresta Perenifólia de Altitude ou "mata do brejo" e Agreste, área de transição entre a Caatinga e Zona da Mata, formada por Florestas Subcaducifólia e Caducifólia (Moreira et al. 1985).

Tratamento taxonômico - Foram realizadas incursões para coleta e observações 'in loco' no período de maio/2016 a junho/2017 em vários municípios (Areia, Bananeiras, Boa Vista, Cabaceiras, Lagoa Seca, Monteiro, Puxinanã, Passagem, Patos e Serra Branca) situados na microrregião de Campina Grande 
e em várias mesorregiões do Estado da Paraíba complementadas por consultas em bases digitalizadas: Species Link, Flora Brasiliensis e Herbário Virtual da Flora e dos Fungos (Reflora), além de visitas aos herbários CSTR, EAN, HACAM e JPB (acrônimos segundo Thiers (2019)). O material coletado durante a execução deste estudo foi incorporado ao Herbário HACAM. Para as consultas de espécimes-tipo, utilizou-se a base de dados JSTOR (2019).

As análises morfológicas foram realizadas no Laboratório de Botânica, Campus I, Universidade Estadual da Paraíba (UEPB). A identificação de gêneros e espécies fundamentou-se em bibliografia especializada (Lay 1950, Cunha 1981, Souza \& Esteves 2002, Tschá et al. 2002, Azevedo \& Valente 2005, Esteves 2006, Alves et al. 2011), com o auxílio de microscópio estereoscópico. A literatura taxonômica também auxiliou na complementação de dados relacionados às estruturas reprodutivas, em casos de materiais incompletos, e na verificação da distribuição geográfica das espécies.

As designações terminológicas das estruturas vegetativas e reprodutivas seguiram Radford et al. (1974) e Harris \& Harris (2001). Este trabalho inclui: a) chave para a separação das espécies; b) descrições e comentários taxonômicos; c) dados de distribuição geográfica, floração e/ou frutificação; d) imagens e estampas em nanquim das espécies de Corchorus e Triumfetta aqui registradas.

\section{Resultados e Discussão}

Foram encontradas sete espécies em quatro gêneros, associadas aos domínios da Caatinga e
Mata Atlântica, sendo as espécies: Apeiba tibourbou Aubl. (figuras 1 e 2) Corchorus argutus Kunth e $C$. hirtus L. (figuras 2, 3 e 4), Luehea ochrophylla Mart. e L. paniculata Mart. (figuras 5 e 6), Triumfetta rhomboidea Jacq. e T. semitriloba Jacq. (figuras 6, 7 e 8). Corchorus argutus compreende uma nova ocorrência para o Estado, sendo encontrada exclusivamente na Caatinga. Apeiba tibourbou, Luehea ochrophylla e Triumfetta semitriloba são exclusivas de Mata Atlântica e as demais espécies encontradas ocorrem em ambos os domínios.

\section{Tratamento taxonômico}

Grewioideae Dippel, Handb. Laubholz. 3: 56-57. 1893.

Ervas, subarbustos, arbustos e árvores. Folhas simples e alternas, pecioladas, com estípulas, por vezes apresentando tricomas secretores. Flores solitárias ou em inflorescências do tipo cimeira. Flores diclamídeas ou raro monoclamídeas. Cálice trímero a pentâmero, dialissépalo ou gamossépalo. Corola tetrâmera a pentâmera, dialipétala, imbricada. Estames numerosos, unidos ou livres entre si, inseridos na base das pétalas ou em andróforos. Gineceu pluricarpelar, ovário súpero, plurilocular ou raramente unilocular, lóculos pluriovulados. Frutos indeiscentes do tipo baga, ou deiscentes dos tipos cápsula ou esquizocarpo. Sementes aladas ou não, discoides, globosas, com endosperma carnoso ou ausente.

Chave para as espécies de Grewioideae registradas na Paraíba

1. Sementes aladas

2. Estames 9-10 por falange; ovário globoso

4. Luehea ochrophylla

2. Estames 6-8 por falange; ovário oblongo 5. Luehea paniculata

1. Sementes não aladas

3. Lâmina foliar com nectários extraflorais marginais

4. Estames 12-15; cápsulas com superfície recoberta por tricomas e acúleos glabros

6. Triumfetta rhomboidea

4. Estames 28-35; cápsulas com superfície glabra e acúleos recobertos por tricomas simples

7. Triumfetta semitriloba

3. Lâmina foliar desprovida de nectários extraflorais

5. Cápsulas globosas, recobertas por cerdas curtas e rígidas 1. Apeiba tibourbou

5. Cápsulas alongado-achatadas, glabrescentes, hirsutas ou vilosas

6. Lâmina foliar estreitamente lanceolada; sementes subquadrangulares com ápice apiculado

2. Corchorus argutus

6. Lâmina foliar oval a largamente elíptica; sementes subtriangulares a retangulares

3. Corchorus hirtus 


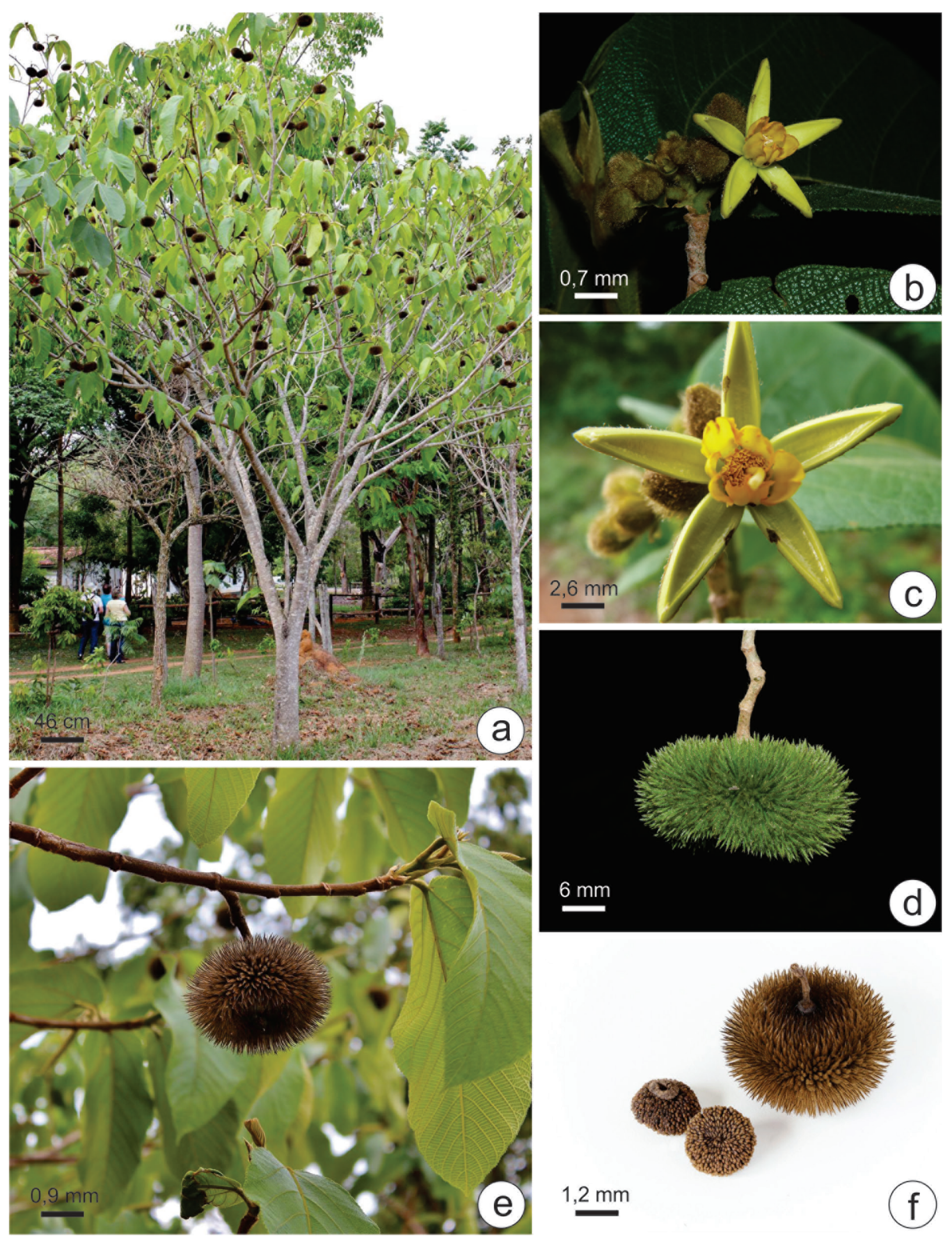

Figura 1. Apeiba tibourbou Aubl.: a. Hábito. b. Ramo reprodutivo. c. Flor em vista frontal. d-f. Frutos. Fotos. a, e, f. M. Mercadante; b, c, d. A. V. Scatigna.

Figure 1. Apeiba tibourbou Aubl.: a. Habit. b. Reproductive branch. c. Flower in front view. d-f. Fruits. Photos. a, e, f. M. Mercadante; b, c, d. A. V. Scatigna. 


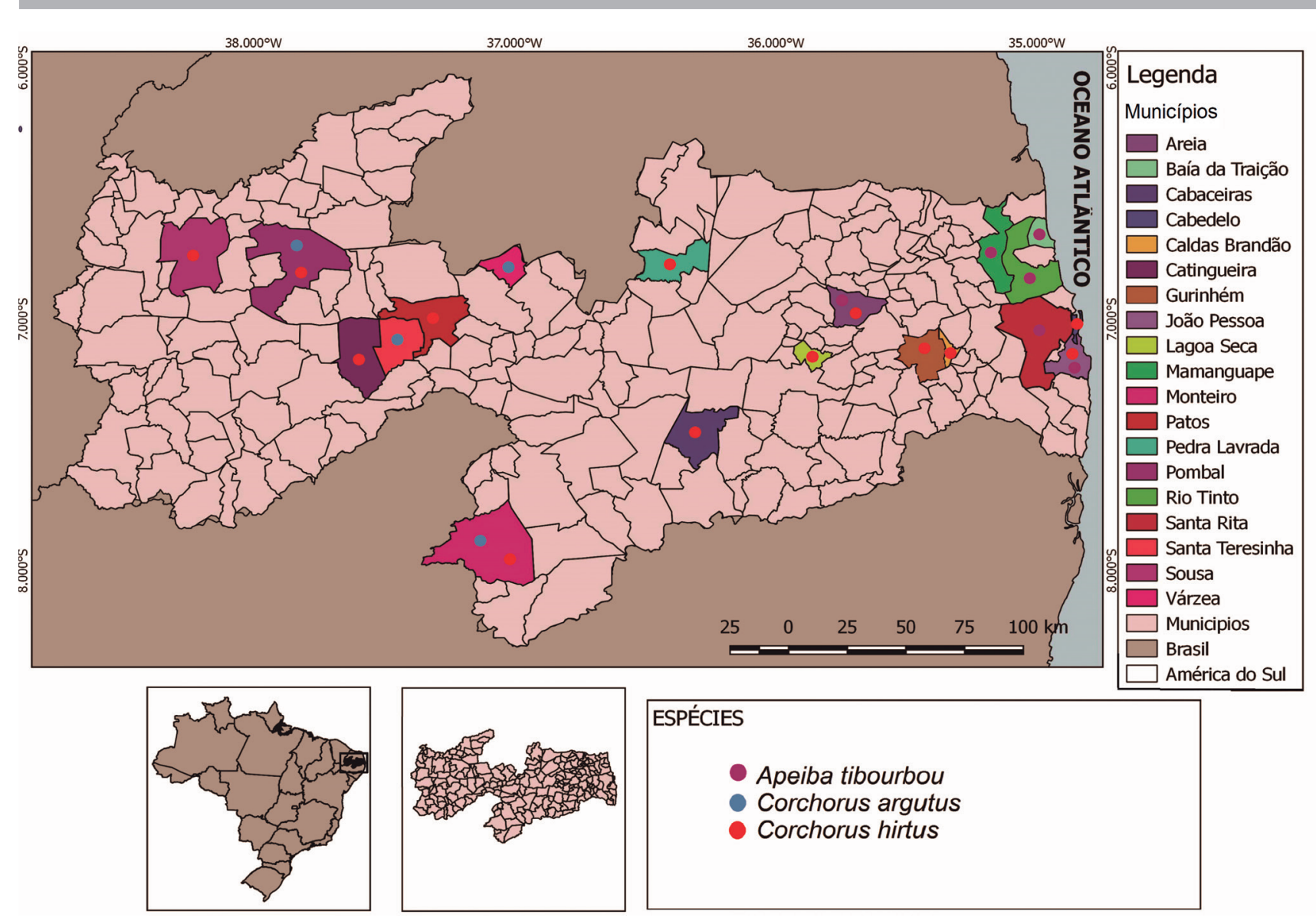

Figura 2. Distribuição geográfica das espécies de Apeiba e Corchorus na área de estudo, Estado Paraíba, Brasil.

Figure 2. Geographical distribution of Apeiba and Corchorus species in the study area, Paraíba State, Brazil.

Apeiba Aubl., Hist. P1. Guiane 1: 537-538, t. 213. 1775.

O gênero possui distribuição neotropical e compreende aproximadamente nove espécies (Dorr \& Meijer 2005, Dorr 2012), sete delas registradas no Brasil, distribuídas nas regiões Norte, Nordeste, Centro-Oeste e Sudeste associadas aos domínios da Amazônia, onde é predominante, bem como na Caatinga, Cerrado e Mata Atlântica (Flora do Brasi). $\mathrm{Na}$ área de estudo, foi registrada a espécie Apeiba tibourbou Aubl.

1. Apeiba tibourbou Aubl., Hist. P1. Guiane 1: 538-541, t. 213. 1775. Tipo: GUIANA FRANCESA, s.d., Aublets.n.(Holótipo: BM000795154!). Imagem digital.

Figuras 1, 2

Árvores, 6-30 m alt.; ramos velutinos, tricomas estrelados. Estípulas 0,5-1,5 cm compr.; pecíolos 1,2-3,7 cm compr.; lâmina 8,0-19,0 × 3,8-9,0 cm, desprovida de nectários extraflorais, largamente elíptica, ápice caudado, base cordada, margem curtamente serreada, face adaxial glabrescente, face abaxial densamente pubescente, especialmente nas nervuras, com tricomas estrelados. Inflorescências opositifólias; brácteas elípticas, ápice acuminado. Flores pediceladas; pedicelos 0,1-0,6 cm compr., hirsutos; sépalas 1,3-2,2 ×0,4-0,8 cm, carnosas, elíptico-lanceoladas, ápice agudo, face adaxial glabra, abaxial velutina; pétalas 1,0-1,8 ×0,5-1,0 cm, obovadas, ápice arredondado, amarelas; estames numerosos; filetes ca. $0,5 \mathrm{~cm}$ compr., livres entre si; estaminódios glabrescentes; ovário ca. $0,4 \mathrm{~cm}$ compr., hirsuto, 8(-10)-locular; estilete ca. 0,5 cm compr.; ginóforo 0,4-0,6 cm compr., glabro. Cápsulas 5,5-7,0 cm compr., globoides, recobertas por cerdas curtas e rígidas, com 1,0-2,0 cm compr., tricomas simples, verdes quando jovens e castanhos na fase adulta, indeiscentes. Sementes globosas.

Material examinado: BRASIL. PARAÍBA: Areia, Mata do Pau Ferro, 9-III-2001, fl., E. Cunha s.n (JPB 26572); Baía da Traição, Aldeia Santa Rita, Mata de 


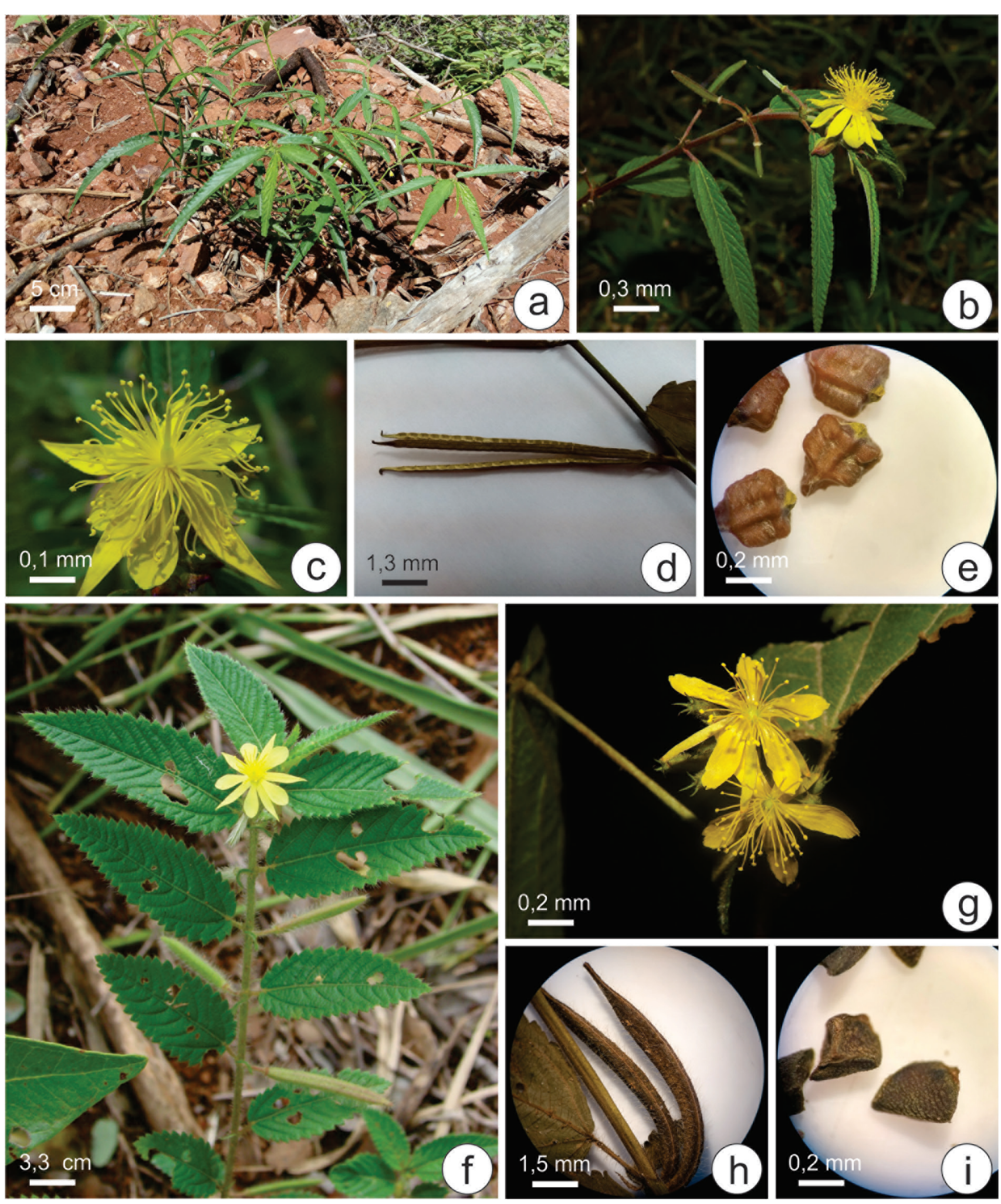

Figura 3. a-e. Corchorus argutus Kunth. a. Hábito. b. Ramo reprodutivo. c. Flor. d. Fruto. e. Sementes. f-i. Corchorus hirtus L.. f. Hábito. g. Ramo reprodutivo. h. Fruto. i. Sementes. Fotos. a: J. I. M. Melo; b, c: J. A. Radins; d, e, g, h, i: F. K. S. Monteiro; f. J: D. Medeiros.

Figure 3. a-e. Corchorus argutus Kunth. a. Habit. b. Reproductive branch. c. Flower. d. Fruit. e. Seeds. f-i. Corchorus hirtus L.. f. Habit. g. Reproductive branch. h. Fruit. i. Seeds. Photos. a: J. I. M. Melo; b, c: J.A. Radins; d, e, g, h, i: F. K. S. Monteiro; f: J. D. Medeiros. 


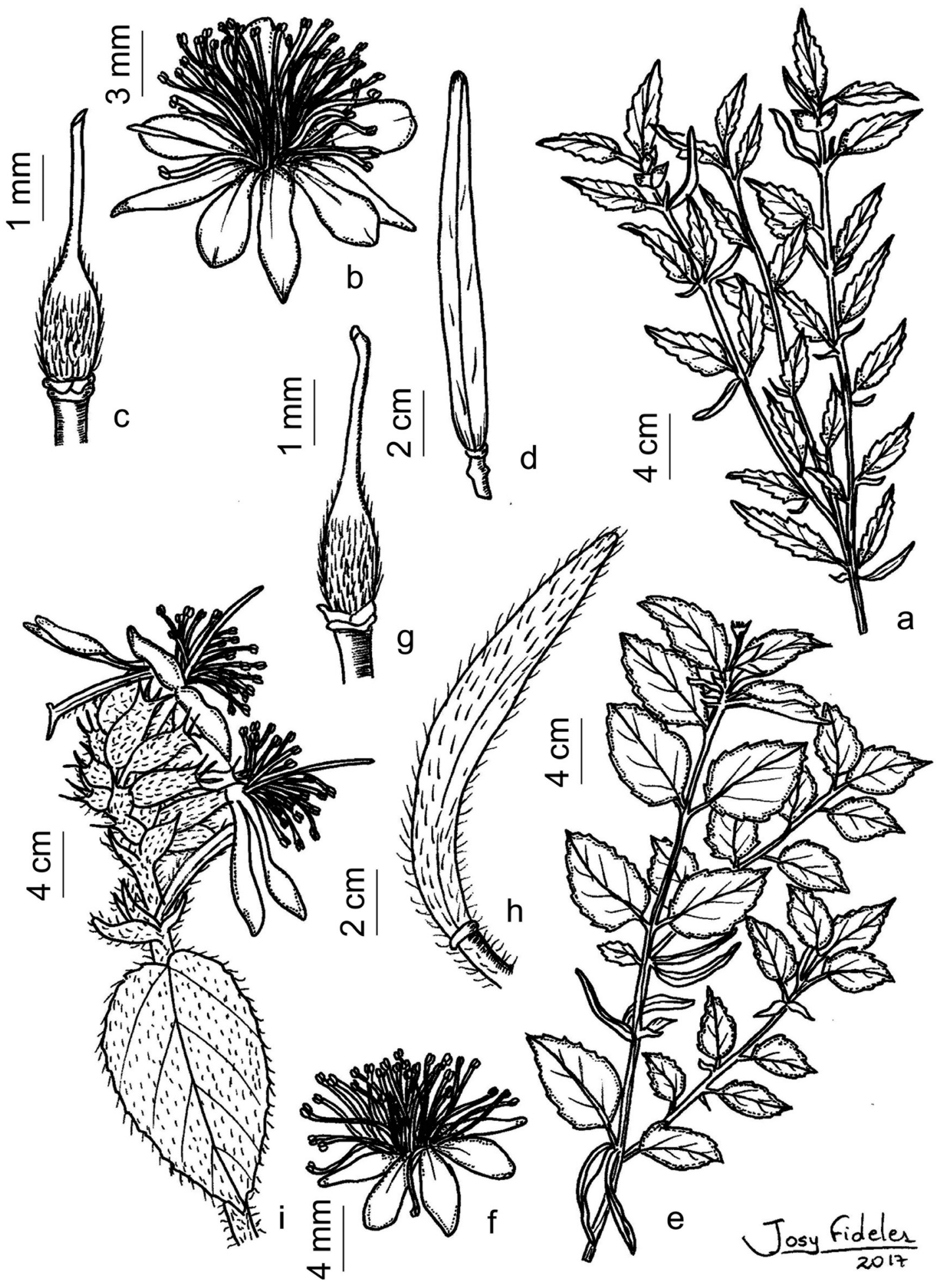

Figura 4. a-d. Corchorus argutus Kunth. a. Hábito. b. Flor. c. Ovário. d. Fruto. e-i: Corchorus hirtus. e. Hábito. f. Flor. g. Ovário. h. Fruto. i. Ramo reprodutivo.

Figure 4. a-d. Corchorus argutus. a. Habit. b. Flower. c. Ovary. d. Fruit. e-i: Corchorus hirtus. e. Habit. f. Flower. g. Ovary. h. Fruit. i. Reproductive branch. 

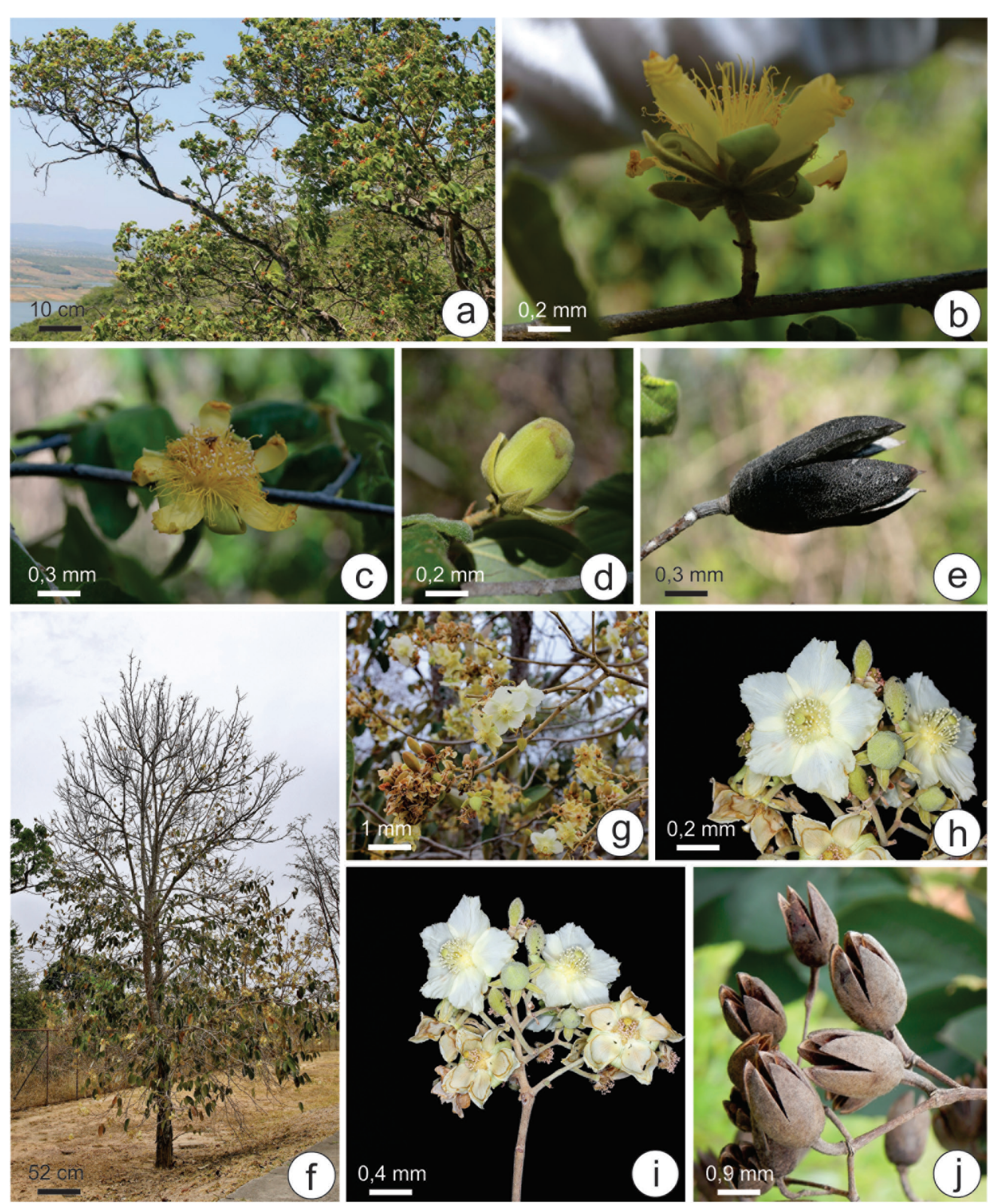

Figura 5. a-e. Luehea ochrophylla. a. Hábito. b. Ramo reprodutivo. c. Flor em vista frontal. d. Botão floral. e. Fruto. f-j. Luehea paniculata. f. Hábito. g-i. Ramos reprodutivos. j. Frutos. Fotos. a-e: F. M. Sobreira; f-i: M. Mercadante; j: J. D. Medeiros.

Figure 5. a-e. Luehea ochrophylla Mart.. a. Habit. b. Reproductive branch. c. Flower in front view. d. Floral bud. e. Fruit. f-j. Luehea paniculata Mart.. f. Habit. g-i. Reproductive branches. j. Fruits. Photos. a-e: F. M. Sobreira; f-i: M. Mercadante; j: J. D. Medeiros. 


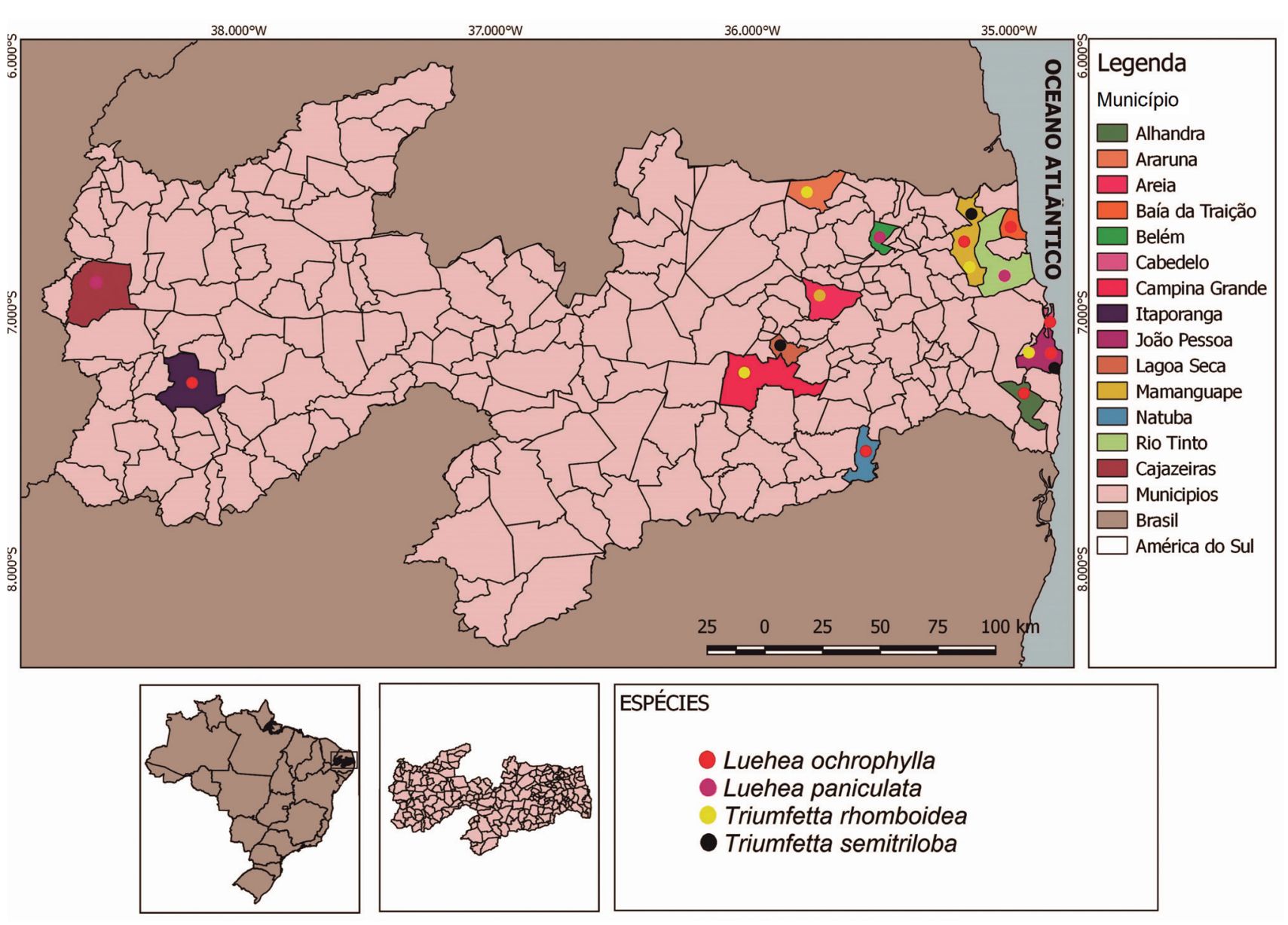

Figura 6. Distribuição geográfica das espécies de Luehea e Triumfetta na área de estudo, Estado Paraíba, Brasil.

Figure 6. Geographic distribution of the Luehea and Triumfetta species in the study area, Paraíba State, Brazil.

Tabuleiro, 25-I-2007, fl., R. Lima et al. 2184 (JPB); João Pessoa, UFPB, Campus I, 3-V-1985, fl. e fr., $O$. T. Moura 702 (JPB); ibid., 22-I-1999, fl., S. R. Santos 8 (JPB); ibid., CCEN, 25-III-1992, fl., E. França 6 (JPB); Mamanguape, 21-XII-1989, fl., L. P. Felix \& E.S. Santana 2633 (JPB); Estação Ecológica do Pau Brasil, 21-IX-2008, fl., S. Satyro \& M. S. Pereira 113 (JPB); Rio Tinto, Mata do Oiteiro, 3-III-2003, fr., $M$. R. Barbosa et al. 2767 (JPB); Santa Rita, Ilha Stuart, 28-I-1994, fl., L. P. Felix 6444 (EAN).

Apeiba tibourbou distribui-se amplamente nas Américas do Sul e Central (Souza \& Esteves 2002). No Brasil, é encontrada nas regiões Norte, Nordeste, Centro-Oeste e Sudeste, associada aos domínios da Amazônia, Caatinga, Cerrado e Mata Atlântica (Flora do Brasil 2020 em constr.). Na área de estudo, foi registrada exclusivamente na Mata Atlântica (figura 2) florida em janeiro, março, maio, setembro e dezembro e frutificada em março e maio.

Esta espécie pode ser reconhecida, principalmente, pelos frutos com 5,5-7,0 cm compr., globoides, recobertos por cerdas curtas e rígidas, verdes quando jovens e castanhos na fase adulta.

Corchorus L., Sp. P1. 1: 529. 1753. 1753.

Subarbustos; ramos hirsutos a glabros. Folhas pecioladas; lâmina inteira, estreitamente lanceolada a lanceolado-elíptica, margem crenada a serreada, faces adaxial e abaxial glabrescentes. Inflorescências cimosas, axilares; brácteas lineares a estreitamente triangulares. Flores com pedicelos velutinos; sépalas 5, livres entre si, lineares a oblongas, ápice agudo; pétalas 5, obovadas, ápice arredondado; estames numerosos; gineceu piloso, ovário oblongo, 2-6 locular. Cápsulas alongado-achatadas, glabrescentes a hirsutas. Sementes retangulares a triangulares.

Possui distribuição tropical e reúne aproximadamente 50 espécies (Souza \& Esteves 2002), seis delas registradas no Brasil, vinculado a todas as regiões nos domínios da Amazônia, Caatinga, Cerrado, Mata Atlântica e Pantanal (Flora do Brasil 


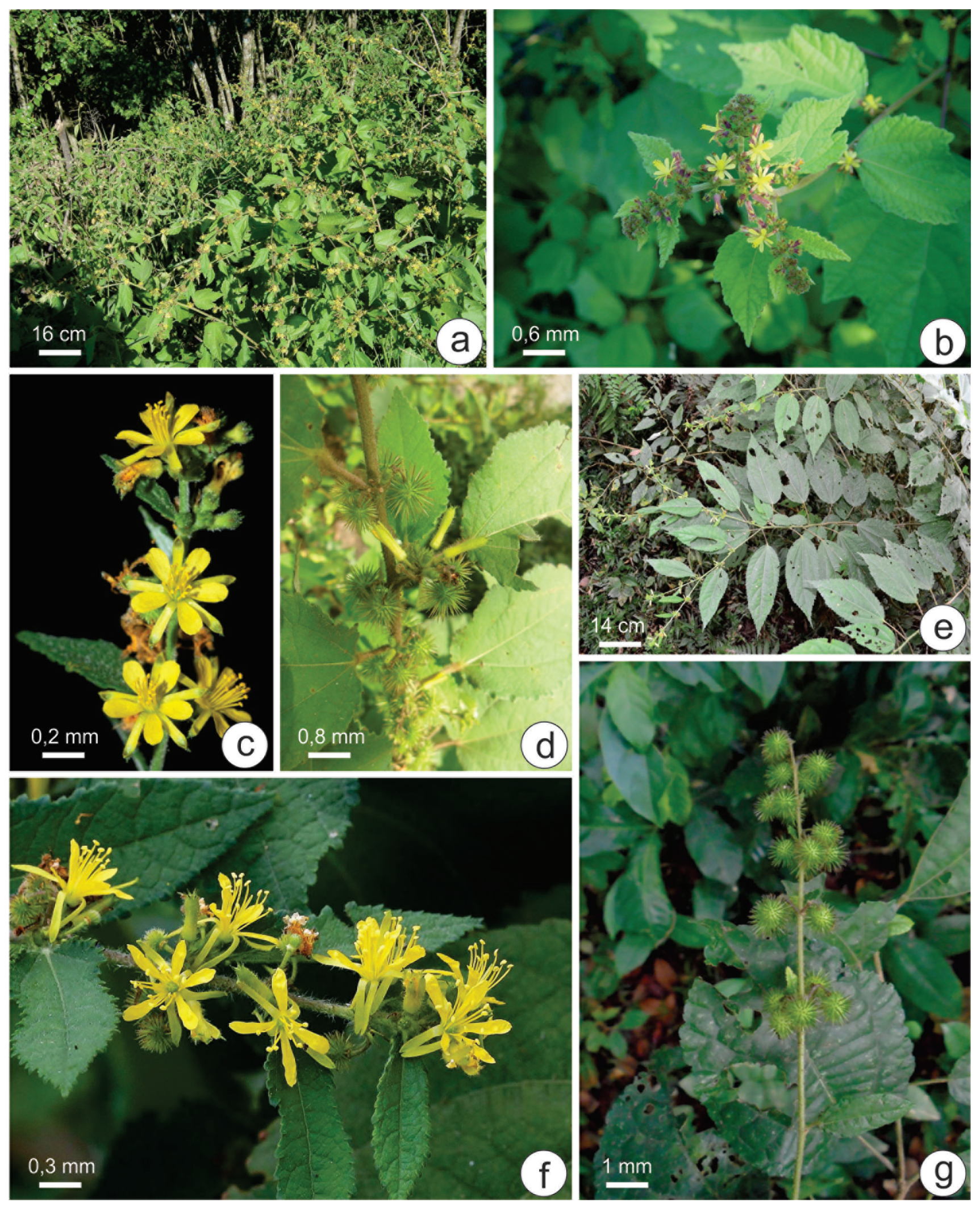

Figura 7. a-d. Triumfetta rhomboidea Jacq.. a. Hábito. b-d. Ramos reprodutivos. e-g. Triumfetta semitriloba Jacq.. e. Hábito. f. Ramo reprodutivo. g. Frutos. Fotos. a, d: W. M. Kranz; b, e: P. Schwirkowski; c: TNG; f: M. Mercadante; g: R. G. Rolim.

Figure 7. a-d. Triumfetta rhomboidea Jacq.. a. Habit. b-d. Reproductive branches. e-g. Triumfetta semitriloba Jacq.. e. Habit. f. Reproductive branch. g. Fruits. Photos. a,d: W. M. Kranz; b, e: P. Schwirkowski; c: TNG; f: M. Mercadante; g: R. G. Rolim. 


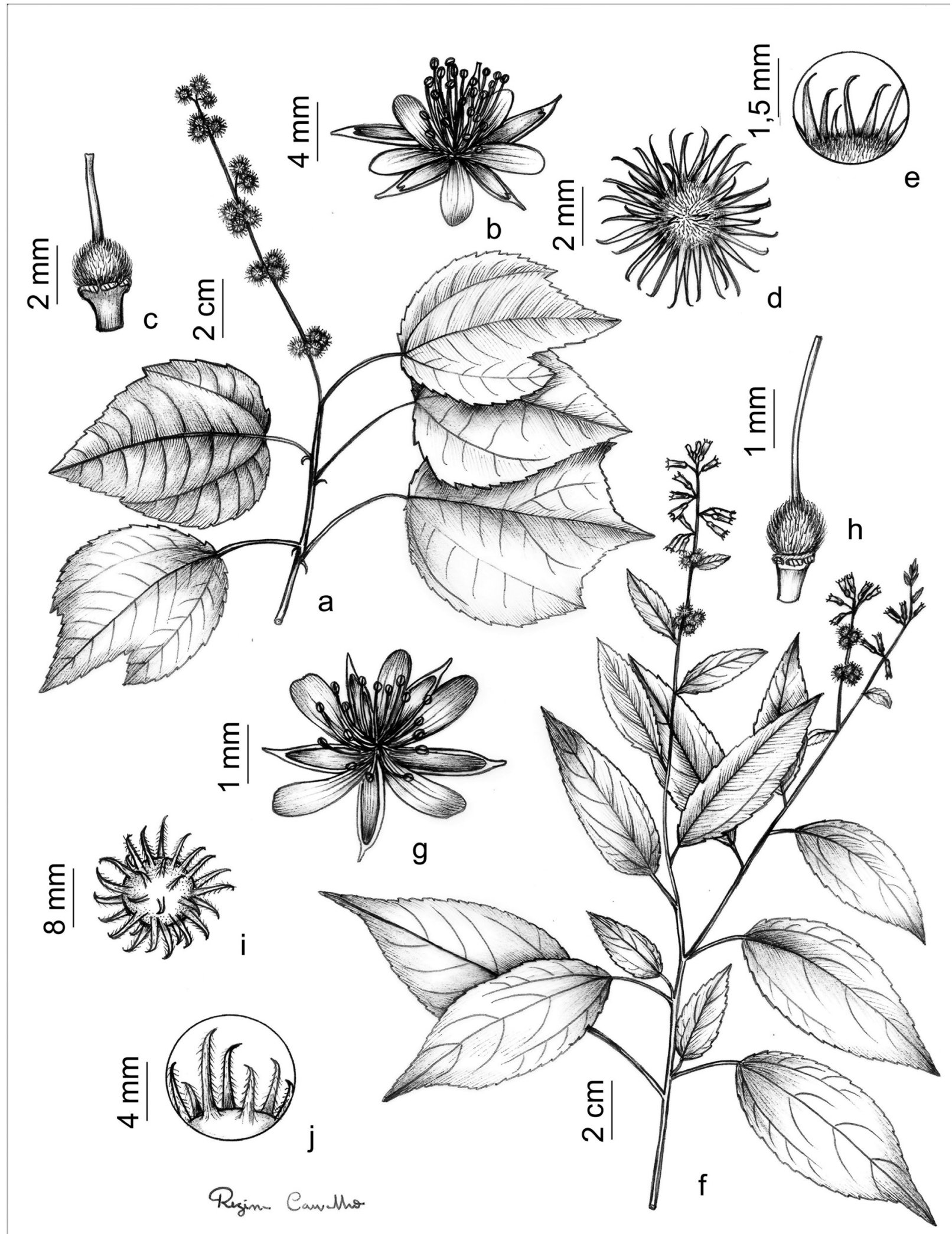

Figura 8: a-e. Triumfetta rhomboidea Jacq.. a. Hábito. b. Flor. c. Gineceu. d. Fruto. e. Detalhe da superfície do fruto. f-j. Triumfetta semitriloba Jacq.. f. Hábito. g. Flor. h. Gineceu. i. Fruto. j. Detalhe da superfície do fruto.

Figure 8: a-e. Triumfetta rhomboidea Jacq.. a. Habit. b. Flower. c. Gynoecium. d. Fruit. e. Detail of fruit surface . f-j. Triumfetta semitriloba Jacq.. f. Habit. g. Flower. h. Gynoecium. i. Fruit. j. Detail of fruit surface. 
2020). Na área de estudo, foram registradas duas espécies: Corchorus argutus Kunth e C. hirtus L., vinculadas à Caatinga e Mata Atlântica.

2. Corchorus argutus Kunth, Nov. Gen. Sp. (quarto ed.) 5: 337-338, 1821 [1822]. Tipo: COLOMBIA, Crescit in Regno-Granatensi, prope Ibague, s.d., Humboldt \& Bonpland s.n. (Holótipo: P 00679623!). Imagem digital.

Figuras 2, 3a-e, 4a-d

Subarbustos, 40-60 cm alt.; ramos glabrescentes a vilosos. Estípulas 0,3-0,6 cm compr., lineares; pecíolos 0,4-0,9 cm compr., hirsutos; lâmina 3,0-11 × 0,5-1,5 cm, estreitamente lanceolada, ápice acuminado, base aguda, margem serreada, superfície glabra em ambas as faces. Inflorescências cimosas, axilares. Flores com pedicelos 0,2-0,3 cm compr., vilosos; sépalas ca. $0,4 \times 0,1 \mathrm{~cm}$, estreitamente elípticas, ápice agudo, glabras na face adaxial e hirsutas na abaxial; pétalas ca. $0,5 \times 0,2 \mathrm{~cm}$, estreitoobovadas, ápice arredondado, glabras em ambas as faces, amarelas; estames múltiplos, filetes ca. $0,5 \mathrm{~cm}$ compr., glabros; gineceu hirsuto, ovário ca. $0,2 \mathrm{~cm}$ compr., oblongo, 4-locular; estilete ca. 0,3 cm compr. Cápsulas 3,0-6,0 cm compr., alongado-achatadas, lineares, glabrescentes a vilosas, tricomas simples adpressos e esparsos, deiscência em três valvas. Sementes subquadrangulares, ápice apiculado.

Material examinado: BRASIL. PARAíba: Monteiro, 1-VI-2017, fl., fr., J. I. M. Melo 41-2017 (HACAM); Pombal, Sítio Maniçoba II, 21-VIII-2011, fl., I. S. Queiroga 128 (CSTR); Santa Terezinha, Fazenda Tamanduá, 3-V-2011, fl., V. Noel et al. 17 (CSRT); Várzea, Cachoeira São Porfírio, 24-VII-2012, C. D. Ferreira \& D. S. Lucena 51 (CSTR).

Distribui-se na América do Sul (Robyns 1964) e, no Brasil, pode ser encontrada em todas as regiões, nos domínios da Amazônia, Caatinga, Cerrado, Mata Atlântica e Pantanal (Flora do Brasil 2020). Na área de estudo, foi encontrada em vegetação de Caatinga (figura 2), compreendendo o primeiro registro da espécie para o Estado, onde foi encontrada florida nos meses de maio, junho e agosto e frutificada em junho.

Corchorus argutus pode ser facilmente reconhecida pelas suas cápsulas alongado-achatadas, lineares, glabrescentes a vilosas, com tricomas simples adpressos e esparsos e deiscência em 3 valvas.

3. Corchorus hirtus L., Sp. P1. (ed. 2) 1: 747. 1762. Tipo: PERU, Huaura, s.d., s.c. (MA817157). Imagem digital.

Figuras 2, 3f-i, 4e-i
Subarbustos, 30-60 cm alt.; ramos hirsutos a glabrescentes. Estípulas 0,3-0,6 cm compr., lineares a estreitamente triangulares; pecíolos $0,3-0,7 \mathrm{~cm}$ compr., hirsutos; lâmina 1,5-6,0 × 1,0-3,0, oval a largamente elíptica, base arredondada, ápice acuminado, margem crenada, ambas as faces com tricomas simples adpressos, esparsos na adaxial, e presentes apenas nas nervuras na face abaxial. Inflorescências cimosas, axilares. Flores com pedicelos 0,2-0,3 cm compr., velutinos; sépalas ca. 0,6 $\times 0,1 \mathrm{~cm}$, estreitamente elípticas, ápice agudo, glabras na face adaxial e velutinas na abaxial; pétalas ca. $0,5 \times$ $0,2 \mathrm{~cm}$, estreito-obovadas, ápice arredondado, glabras em ambas as faces, amarelas; estames múltiplos, filetes 0,4-0,5 cm compr., glabros; gineceu piloso, ovário ca. 0,2 cm compr., oblongo, 4-6-locular; estilete ca. 0,2 cm compr. Cápsulas 2,0-3,0 cm compr., alongadoachatadas, levemente curvadas, hirsutas, com tricomas simples patentes, deiscência em 2 valvas. Sementes subtriangulares a retangulares.

Material examinado: BRASIL. PARAíbA: AreiaAlagoa Grande, margem da estrada entre os dois municípios, 5-XI-1982, fl., fr., A.D. Silva et al. 1076 (JPB); Cabaceiras, Sítio Bravo, fl., fr., 14-IV-1992, V.L. Nascimento \& C. F. Martins 93 (JPB); Cabedelo, 29-II-1980, fr., L. P. Xavier s.n. (JPB 4036); Cajá, 4-X-1988, fl., ft., L. P. Felix \& E.C. Silva s.n. (EAN9199); Catingueira, Serra da Catingueira, 3-III-2013, fl., I.M. Campos 1-2013 (CSTR); Gurinhém, Ponto 6, Próximo ao açude, 3-XI-1987, fl., fr., L. P. Felix \& E. C. Silva 1881 (EAN); João Pessoa, Mangabeira I, 7-IX-1987, fl., fr., O. T. Moura 230 (JPB); ibid., Jardim Botânico, 8-VIII-2002, fl., fr., Eusébio s.n. (JPB 31103); ibid., Mangabeira VII, 13-VII-1993, fl., fr., O.T. Moura 1042 (JPB); Lagoa Seca, estrada para o Sítio Conceição, fl., fr., 10-I-2016, F.K.S. Monteiro \& A. S. Pinto 31 (HACAM); Monteiro, 1-VI-2017, fl., fr., J.I.M. Melo 40-2017 (HACAM); ibid., Fazenda Olho D’Água, 13-IV-2009, fl., fr., J.G. Carvalho-Sobrinho 2192 (HVASF); Patos, Serra do Trapiá, 9-III-2013, fl., E.F. Lucena 3 (CSTR); Pedra Lavrada, Serra da Flecha, 30-IV-2007, fl., fr., P.C. Gadelha-Neto et al. 1687 (JPB); Pombal, Sítio Maniçoba II, 29-V-2011, fl., fr., I.S. Queiroga 52 (CSTR); Sousa, 03-III-1996, fl., P.C. Gadelha-Neto 328 (JPB).

Espécie amplamente distribuída nas regiões tropicais (Souza \& Esteves 2002). No Brasil, ocorre em todas as regiões associada aos domínios da 
Amazônia, Caatinga, Cerrado, Mata Atlântica e Pantanal (Flora do Brasil 2020). Na área de estudo, foi encontrada em áreas de Caatinga e Mata Atlântica, incluindo os brejos de altitude (figura 2), florida e frutificada nos meses de janeiro a novembro.

Esta espécie é afim de $C$. argutus especialmente por compartilharem o tipo de hábito e a morfologia floral. Entretanto, podem ser diferenciadas, principalmente, pelo formato da lâmina foliar, estreitamente lanceolada em $C$. argutus vs. oval a largamente elíptica em $C$. hirtus, pela deiscência dos frutos, 3-valvar em $C$. argutus vs. 2-valvar em $C$. hirtus e pela forma das sementes, subquadrangulares com ápice apiculado em $C$. argutus vs. subtriangulares a retangulares em C. hirtus.

Luehea Willd., Ges. Naturf. Freunde Berlin Neue Schriften. 3: 410. 1801.

Árvores; ramos glabrescentes a pubescentes, tricomas estrelados. Folhas com estípulas; pecioladas; lâmina inteira, elíptica, oblonga, obovada ou oval, margem serreada. Inflorescências cimosas, axilares ou terminais. Flores pediceladas; sépalas livres entre si, estreito-ovais a estreitamente elípticas; pétalas linear-lanceoladas, obovais ou ovais, alvas, creme ou róseas; estames numerosos, agrupados em falanges 5-10, anteras lineares, deiscência rimosas; presença de 1 estaminódio por falange; ovário globóide, elipsoide ou oblongo, 5-locular. Cápsulas lenhosas, leve a fortemente anguladas, pubescentes a glabrescentes, tricomas estrelados. Sementes ovoides, aladas.

Gênero de distribuição neotropical, compreendendo aproximadamente 16 espécies (Cunha 1981), dentre as quais, dez estão registradas no Brasil, associadas a todas as regiões nos domínios da Amazônia, Caatinga, Cerrado, Mata Atlântica e Pantanal (Flora do Brasil 2020). Na área de estudo, foram encontradas duas espécies: Luehea ochrophylla Mart. e Luehea paniculata Mart.

4. Luehea ochrophylla Mart., Flora 24 (2, Beibl.): 50. 1841. Tipo: BRASIL, s.d., Carl Martius 523 (Holótipo: B, destruído; Isótipos: P02142935!, MO 309032!, NY00415479!). Imagem digital.

Figuras 5a-e, 6

Árvores, 4-8 m alt.; ramos lenhosos, pubescentes, tricomas estrelados. Estípulas 0,1-0,8 cm compr.; pecíolos $0,5-0,8 \mathrm{~cm}$ compr., pubescentes; lâmina 9,5-15,8 × 3,9-7,8 cm, elíptica, ápice acuminado, base obtusa, margem serreada, face adaxial pubescente, abaxial glabrescente. Inflorescências terminais. Flores com pedicelos 0,4-0,7 cm compr., pubescentes; bractéolas 0,7-0,9 cm compr., pubescentes; sépalas ca. $0,8 \times 0,3 \mathrm{~cm}$, estreitamente elípticas, ápice agudo, face adaxial glabra, abaxial pubescente; pétalas ca. $0,7 \times 0,3 \mathrm{~cm}$, lanceoladas a ovadas, ápice agudo, alvas a cremes; estames numerosos, 9-10 por falange; filetes ca. 0,6 cm compr.; estaminódios ca. 0,3 cm compr.; gineceu hirsuto, ovário ca. $0,3 \mathrm{~cm}$ compr., globóide, 5-locular; estilete ca. 0,4 cm compr. Cápsulas 0,5-2,0 $\times 0,3-0,9 \mathrm{~cm}$, oblongas, lenhosas, deiscência em 4 valvas. Sementes aladas em toda a superfície.

Material examinado: BRASIL. PARAÍBA: Alhandra, Mata Redonda, Tabuleiro, 7-IV-2003, fl., T.M.G. Veloso 338 (JPB); Baía da Traição, Aldeia Traiçoeira, 24-I-2007, fl., R. Lima et al. 2173 (JPB); Cabedelo, Mata do Amém, 31-I-2000, fl., fr., A.F. Pontes \& J.R. Lima 397 (JPB); ibid., 1-III-2000, fl., fr., A.F. Pontes \& J.R. Lima 443 (JPB); Itaporanga, Fazenda Cafula e Lagoa, 21-XI-2014, fl., fr., P.F. Souza 43 (CSTR); João Pessoa, Campus da UFPB, 19-IV-1978, fl., M.F. Agra 455 (JPB); ibid., 5-XI-1981, fl., fr., Montenegro 12 (JPB); ibid., 11-II-1993, fl., P.C. Gadelha-Neto 06 (JPB); ibid., UFPB, 29-V-1980, fl., C. Alonso s.n. (JPB 56678); ibid., Granja Santa Fé, 2-XII-1971, fl., fr., L. P. Xavier s.n. (JPB 4059); ibid., Gramame, Parque Ecológico Augusto dos Anjos, 12-I-2009, fl., A.C.C. Almeida \& G.B. Freitas 168 (JPB); ibid., Rio Jacarapé, 16-III-1991, fl., M.R. Barbosa 1175 (JPB); Mamanguape, Estação Ecológica do Pau Brasil, 6-I-2008, fl., fr., S. Satyro \& M. S. Pereira 11 (JPB); Natuba, 12-I-2000, fl., M.R. Barbosa et al. 1897 (JPB).

Distribui-se na Argentina, Brasil e Paraguai (Cunha 1981) e, no Brasil, possui registros nas regiões Norte, Nordeste e Sudeste, associada aos domínios da Amazônia, Caatinga, Cerrado e Mata Atlântica (Flora do Brasil 2020). Na área de estudo, foi encontrada na Mata Atlântica, incluindo zonas litorâneas (figura 6). Coletada florida entre janeiro a maio e em novembro e dezembro, e frutificada de novembro a janeiro e em março.

A espécie pode ser facilmente reconhecida por seus ramos lenhosos, com todas as partes predominantemente pubescentes, e pelas cápsulas oblongas, lenhosas, com até 2,0 cm de comprimento. Diferencia-se de Luehea paniculata em aspectos como o formato do ovário, globóide em L. ochrophylla vs. oblongo em $L$. paniculata, e pelo número de estames por falange, sendo 9 a 10366 estames em $L$. ochrophylla vs. 6 a 8 em L. paniculata. 
5. Luehea paniculata Mart., Nov. Gen. Sp. P1. 1: 100, pl. 62. 1826. Tipo: BRASIL, s.d., Carl Martius 263(Holótipo: M0210162!, imagem M661!; Isótipos: MO1890136!, MO1890135!). Imagem digital. Figuras 5f-j, 6

Árvores, 5-18 m alt.; ramos estriados, glabrescentes a pubescentes. Estípulas $0,3-0,5 \mathrm{~cm}$ compr., lineares; pecíolos 0,6-0,8 cm compr., seríceos; lâmina 5,0-10,8 × 2,2-4,6 cm, elíptica a oblonga, ápice agudo a acuminado, base obtusa, margem serreada, face adaxial glabrescente, face abaxial serícea com tricomas estrelados. Inflorescências paniculadas, axilares ou terminais. Flores com pedicelos $0,2-1,0 \mathrm{~cm}$ compr., seríceos; bractéolas $0,4-0,8 \mathrm{~cm}$ compr., tricomas estrelados em ambas as faces; sépalas ca. $0,9 \times 0,4 \mathrm{~cm}$, estreitamente oblongas, ápice agudo a acuminado, face adaxial glabra, face abaxial serícea; pétalas ca. $0,8 \times 0,4 \mathrm{~cm}$, lanceoladas a ovadas, ápice agudo, alvas; estames numerosos (6-8) em cada falange; filetes ca. 0,7 cm compr.; estaminódio ca. $0,5 \mathrm{~cm}$ compr.; gineceu glabrescente, ovário ca. $0,4 \mathrm{~cm}$ compr., oblongo, 5-locular; estilete ca. 0,4 cm compr. Cápsulas 0,7-2,0 × 0,4-1,1 cm, obovadas, lenhosas, deiscência em 5 valvas. Sementes aladas no ápice.

Material examinado: BRASIL. PARAíBA: Belém, 26-XI-1942, fl., fr., L. Xavier s.n. (JPB 1103); Cajazeiras, 26-I-2015, fl., fr., F.M. Sobreira 40 (HACAM); Rio Tinto, Sema III, Mata do Maracujá, 23-V-1990, fl., fr., L.P. Felix \& E. Santana s.n. (JPB 18794).

Ocorre na América do Sul, sendo encontrada na Bolívia, Brasil, Peru, Colômbia e Paraguai (Cunha 1981). No Brasil, foi registrada em todas as regiões, vinculada aos domínios da Amazônia, Caatinga, Cerrado, Mata Atlântica e Pantanal (Flora do Brasil 2020). Na Paraíba, ocorre em domínios de Caatinga e Mata Atlântica, sendo elemento frequente em borda de mata (figura 6). Coletada com flores e frutos em janeiro, maio e novembro.

Luehea paniculata compartilha características gerais com L. ochrophylla. Ver comentário da espécie anterior.

Triumfetta L., Sp. P1. 1: 444. 1753.

Arbustos; ramos pubescentes, com tricomas estrelados. Folhas pecioladas; lâmina inteira a 3-lobada, oval, provida de nectários extraflorais nas margens, estas crenadas a serreadas. Inflorescências cimosas, axilares. Flores pediceladas; brácteas caducas, triangulares; sépalas livres entre si, leve ou profundamente cuculadas; pétalas obovadas a espatuladas, amarelas; estames numerosos, livres entre si, anteras lineares; ovário globóide, 3-4-locular; presença de ginóforo com glândulas de formas variadas. Cápsulas globosas com acúleos uncinados. Sementes piriformes ou ovoides.

O gênero distribui-se na África, Ásia, América e Austrália concentrado, principalmente, na América Central, reunindo aproximadamente 150 espécies (Lay 1950), nove delas registradas no Brasil vinculadas a todas as regiões nos domínios da Amazônia, Caatinga, Cerrado e Mata Atlântica (Flora do Brasil 2020). $\mathrm{Na}$ área de estudo, foram registradas duas espécies: Triumfetta rhomboidea Jacq. e Triumfetta semitriloba Jacq.

6. Triumfetta rhomboidea Jacq., Enum. Syst. P1.: 22. 1760. Tipo: WEST INDIES, N.J. Jacquin s.n. (Holótipo: BM 000795085!). Imagem digital.

Figuras 6, 7a-d, 8a-e

Arbustos, 1-3 m alt.; ramos pubescentes, com tricomas estrelados. Estípulas 0,2-0,4 cm compr.; pecíolos 3,9-6,5 cm; lâmina 9-11 × 7-9,5 cm, inteira a frequentemente 3-lobada, oval, ápice acuminado, base arredondada, margem serreada com nectários presentes, face adaxial levemente pubescente, face abaxial densamente pubescente. Inflorescências cimosas, axilares. Flores com pedicelos $0,1-0,3 \mathrm{~cm}$ compr.; sépalas ca. $0,5 \times 0,1 \mathrm{~cm}$, estreitamente oblongas, ápice arredondado, face adaxial glabra, face abaxial com tricomas estrelados, amarelas, ocasionalmente com manchas violetas no ápice; pétalas ca. $0,4 \times 0,2 \mathrm{~cm}$, estreitamente obovadas a oblongas, ápice arredondado, amarelas; estames numerosos (12-15), filetes ca. 0,3 cm compr.; ovário ca. 0,2 cm compr., globóide, piloso, 3-4 locular; estilete ca. 0,2 cm compr. Cápsulas 0,5-1,0 cm compr. (incluindo os acúleos), globoides, indeiscentes, superfície recoberta por tricomas, acúleos glabros. Sementes ovoides.

Material examinado: BRASIL. PARAÍBA: Araruna, Parque Estadual Pedra da Boca, 28-IX-2002, fl., fr., $R$. Lima et al. 1693 (JPB); Areia, Mata do Pau Ferro, 5-X1999, fr., M.R. Barbosa 1817 (JPB); Campina Grande, São José da Mata, VI-1990, fl., M.F. Agra s.n. (JPB 19248); João Pessoa, Mangabeira I, 23-IX-1987, fl., fr., O.T. Moura 269 (JPB); Mamanguape, Camaratuba, 21-VIII-1941, fl., fr., L. Xavier s.n. (JPB 216). 
Espécie distribuída na América do Sul (Lay 1950) e, no Brasil, ocorre em todas as regiões associada aos domínios da Amazônia, Caatinga, Cerrado e Mata Atlântica (Flora do Brasil 2020). Na área de estudo, foi encontrada em áreas de Caatinga e Mata Atlântica (figura 6), florida em junho, agosto e setembro e frutificada de agosto a outubro.

Caracteriza-se, principalmente, por apresentar lâmina foliar inteira a frequentemente trilobada, e frutos com a superfície recoberta por tricomas e acúleos glabros.

7. Triumfetta semitriloba Jacq., Enum. Syst. P1. 22. 1760. Tipo: WESTINDIES. in Caribaearum fruticetis, N.J. Jacquin s.n. (Holótipo: BM000554845!). Imagem digital.

Figuras $6,7 \mathrm{e}-\mathrm{g}, 8 \mathrm{f}-\mathrm{j}$

Arbustos, 1-2 m alt.; ramos pubescentes, tricomas estrelados. Estípulas 0,1-0,4 cm compr.; pecíolos 0,6-2,5 cm compr.; lâmina 1,6-10,5 × 0,9-5,2 cm, inteira a 3-lobada, oval a largamente elíptica, ápice acuminado, base obtusa, margem serreada com nectários presentes, face adaxial glabrescente, face abaxial densamente pubescente. Inflorescência cimosa, axilar. Flores com pedicelos $0,1-0,3 \mathrm{~cm}$ compr.; sépalas $0,6 \times 0,1 \mathrm{~cm}$, estreitamente oblongas, ápice acuminado, face adaxial glabra, face abaxial com tricomas estrelados, amarelas levemente esverdeadas no ápice; pétalas $0,5 \times 0,2 \mathrm{~cm}$, estreitamente obovadas a oblongas, ápice arredondado, amarelas; estames numerosos (28-35); filetes ca. 0,4 cm compr.; ovário ca. 0,2 cm compr., globóide, piloso, 3-4-locular; estilete ca. 0,3 cm compr. Cápsulas 0,4-1,2 cm compr.. (incluindo os acúleos), globosas, superfície glabra, acúleos recobertos por tricomas simples, indeiscentes. Sementes piriformes.

Material examinado: BRASIL. PARAÍBA: João Pessoa, $15^{\circ}$ BIMtz, 11-IX-2009, fr., A.H.L. Cariri \& G.B. Freitas 73 (JPB); Lagoa Seca, 27-VI-1980, fl., fr., M.F. Agra 297 (JPB); ibid., Fazenda Ipuarana, 29-VII-2001, fl., fr., C.E.L. Lourenço \& M.C. Carneiro 231 (JPB); João Pessoa, Av. João Machado, 1-VI-1941, fl., L. Xavier s.n (JPB 185); Mamanguape, Reserva, 6-VII-1988, fl., L.P. Felix \& C.A.B. Miranda s.n. (JPB 7307); ibid., Sema II, 31-VIII-1989, fl., fr., L.P. Felix \& E.S. Santana s.n. (JPB 9159).

Espécie de distribuição pantropical (Lay 1950). No Brasil, ocorre em todas as regiões, vinculada aos domínios da Amazônia, Caatinga, Cerrado e Mata
Atlântica (Flora do Brasil 2020). Na área de estudo, foi encontrada na Mata Atlântica, inclusive em ambiente ciliar (figura 6). Coletada florida de junho a agosto e frutificada de junho a setembro.

Espécie morfologicamente relacionada a Triumfetta rhomboidea na morfologia geral, podendo ser facilmente, dentre outras características, através do número de estames, 12-15 em T. rhomboidea vs. 28-35 em T. semitriloba (Alves et al. 2011, Tschá et al. 2002) e pelos frutos, que inversamente a T. rhomboidea que apresenta frutos de superfície recoberta por tricomas e acúleos glabros, em T. semitriloba possuem superfície glabra e acúleos recobertos por tricomas.

\section{Conclusão}

O número de espécies registrado na área de estudo corresponde a aproximadamente $12 \%$ do total das espécies de Grewioideae encontradas no Brasil. No entanto, dentre as espécies encontradas na Paraíba, nenhuma delas é endêmica do território brasileiro, porém Corchorus argutus está sendo registrada pela primeira vez para o Estado.

As espécies estão associadas aos domínios da Caatinga e Mata Atlântica, uma restrita à primeira (Corchorus argutus), três exclusivas desta segunda (Apeiba tibourbou, Luehea ochrophylla e Triumfetta semitriloba) e as demais registradas em ambos os domínios (Corchorus hirtus, Luehea paniculata e Triumfetta rhomboidea). Corchorus hirtus foi a mais amplamente distribuída, enquanto a mais restrita foi L. paniculata.

Os principais caracteres utilizados para a separação de gêneros e espécies foram: formato da lâmina foliar e os órgãos reprodutivos (principalmente relacionados ao ovário, frutos e sementes).

Baseando-se nos resultados desse trabalho, é oportuno destacar a contribuição dos estudos taxonômicos para o conhecimento da biodiversidade local, haja vista que, através destes, possibilita-se ainda a atualização e ampliação constante dos acervos e bancos de dados dos herbários, sobremaneira para Grewioideae (e Malvaceae) para a flora local, regional e nacional.

\section{Agradecimentos}

A primeira Autora agradece à Universidade Estadual da Paraíba (UEPB), por todos os recursos oferecidos para a realização deste trabalho, especialmente ao Programa de Iniciação Científica 
(PIC) pela Bolsa concedida (Cota 2016-2017) e ao Setor de Transportes. JIM Melo agradece ao Conselho Nacional de Desenvolvimento Científico e Tecnológico (CNPq), pela Bolsa de Produtividade em Pesquisa (Proc. n. 303867/2015-9). Ao EditorAssociado responsável pela tramitação desse trabalho e aos revisores anônimos pelas valiosas sugestões.

\section{Literatura citada}

AESA (Agência Executiva de Gestão das Águas), Paraíba). 2006. Relatório final do Plano Estadual de Recursos Hídricos. Disponível em http://www.aesa. pb.gov.br/aesa-website/ (acesso em 14-IX-2019).

Alverson, W.S., Whitlock, B.A., Nyffeler, R., Bayer, C. \& Baum, D.A. 1999. Phylogeny of the core Malvales: evidence from ndhF sequence data. American Journal of Botany 86: 1474-1486.

Alves, I.M., Dantas, I.C., Melo, J.I.M. \& Felismino, D.C. 2011. A família Malvaceae sensu lato em uma área do Agreste paraibano, nordeste do Brasil. Revista de Biologia e Farmácia 3: 1-20.

APG IV. 2016. An update of the Angiosperm Phylogeny Group classification for the orders and families of flowering plants: APG IV. Botanical Journal of the Linnean Society 181: 1-20.

Araújo, E.L.S., Silva, M.F.F., Muniz, A.L.V. \& Alvino, F.O. 2007. Levantamento de produtos florestais não madeireiros em áreas de sucessão secundária no município de Bragança-PA. Revista Brasileira de Biociências 5: 234-236.

Azevedo, M.A.M. \& Valente, M.C. 2005. Tiliaceae da Mata de Encosta do Jardim Botânico do Rio de Janeiro e arredores, Rio de Janeiro, RJ. Arquivos do Museu Nacional 63: 631-637.

Bayer, C., Fay, M. F., Bruijn, A.Y., Savolainen, V., Morton, C.M., Kubitzki, K., Alverson, W.S. \& Chase, M.W. 1999. Support for an expanded family concept of Malvaceae within a recircumscribed order Malvales: a combined analysis of plastid atpB and rbcL DNA sequences. Botanical Journal of the Linnean Society 129: 267-303.

Bayer, C. \& Kubitzki, K. Malvaceae. 2003. In: K. Kubitzki \& J.W. Kadereit (eds.). The families and genera of vascular plants. Springer-Verlag, Berlim, pp. 225-311.

Brunken, U. \& Muellner, A.N. 2012. A new tribal classification of Grewioideae (Malvaceae) based on morphological and molecular phylogenetic evidence. Systematic Botany 37: 699-711.

Corrêa, M.P. 1985. Dicionário das plantas úteis do Brasil e das plantas exóticas cultivadas, v.6. Imprensa Nacional, Rio de Janeiro.

CRIA(Centro de Referência em Informação Ambiental). 2019. Flora Brasiliensis. Disponível em http:// florabrasiliensis.cria.org.br/index (acesso em 05-IX2019).
Cronquist, A. 1981. An integrated system of classification of flowering plants. Columbia University Press, New York.

Cunha, M.C.S. 1981. Revisão das espécies de Luehea Willd. (Tiliaceae), ocorrentes no estado do Rio de Janeiro. Dissertação de Mestrado, Universidade Federal do Rio de Janeiro, Rio de Janeiro.

Dorr, L.J. 2012. Apeiba trombetensis (Malvaceae: Grewioideae), a new species from northern Brazil. Brittonia 64: 374-380.

Dorr, L.J. \& Meijer, W. 2005. Tiliaceae. In: P.E. Berry, K. Yatskievych \& B. K. Holst (eds.). Flora of the Venezuelan Guayana. Missouri Botanical Garden Press, St. Louis, v. 9, pp. 343-362.

Esteves, G.L. 2006. Flora da Reserva Ducke, Amazonas, Brasil: Tiliaceae. Rodriguésia 57: 367-368.

Fernandes-Júnior, A.J., Ferrucci, M.S. \& Gil, A.D. S. 2018. Triumfetta multiglandulosa (Malvaceae, Grewioideae): A New Species from the Remnants of the Brazilian Atlantic Forest in the State of Goiás, Brazil. Systematic Botany 43: 1005-1010.

Grings, M. 2011. O gênero Pavonia Cav.(Malvaceae) no Rio Grande do Sul, Brasil. Tese de Mestrado, Universidade Federal do Rio Grande do Sul, Porto Alegre.

Harris, J.G. \& Harris, M.W. 2001. Plant Identification Terminology. An Illustrated Glossary. 2 ed. Spring Lake, Utah.

Heywood, V.H. 1978. Flowering Plants of the world. Oxford: Oxford University Press.

IDEME (Instituto de Desenvolvimento Municipal e Estadual). 2015. Anuário Estatístico da Paraíba: Caracterização Territorial. Disponível em http://www. ideme.pb.gov.br (acesso em: 14-XI-2017).

Jardim Botânico do Rio de Janeiro. 2018. Flora do Brasil (em construção). Disponível em http://floradobrasil.jbrj. gov.br/ (acesso em 10-VII-2018).

JSTOR Global Plants. 2019. Disponível em https://plants. jstor.org/ (acesso em 17-IX-2019).

Judd, W.S. \& Manchester, S.R. 1997. Circumscription of Malvaceae (Malvales) as determined by a preliminary cladistics analysis of morphological, anatomical, palynological, and chemical characters. Brittonia 49: 384-405.

Lasure, A., Van Poel, B., Pieters, L., Claeys, M., Gupta, M., Berghe, D. V. \& Vlietinck, A. J. 1994. Complement-inhibiting properties of Apeiba tibourbou. Planta Medica 60: 276-277.

Lay, K.K. 1950. The American species of Triumfetta L. Annals of the Missouri Botanical Garden, St. Louis 37: 315-395.

Flora do Brasil 2020 (em construção). 2019. Malvaceae. Disponível em http://floradobrasil.jbrj.gov.br/reflora/ floradobrasil/FB156 (acesso em 29-I-2019). 
Moreira, E.R.F., Carvalho, F.A.F. \& Carvalho, M.G.F. 1985. Atlas Geográfico do Estado da Paraíba. Universidade Federal da Paraíba, Grafset, João Pessoa.

Nyffeler, R., Bayer, C., Alverson, W.S., Yen, A., Whitlock, B.A., Chase, M.W. \& Baum, D.A. 2005. Phylogenetic analysis of the Malvadendrina clade (Malvaceae s.1.) based on plastid DNA sequences. Organisms, Diversity \& Evolution 5: 109-123.

Radford, A.E., Dickison, W.C., Massey, J.R. \& Bell, C.R. 1974. Vascular Plant Systematics. Harper Collins, Chicago.

Robyns, A. 1964. Flora of Panama: Tiliaceae. Annals of the Missouri Botanical Garden 51: 1-33.
Silva, M.R.D.M. 2014. Malvaceae s.l. Juss. da Serra Negra, Minas Gerais, Brasil. Tese de Mestrado, Universidade Federal de Juiz de Fora, Juiz de Fora.

Simpson, M.G. 2006. Plant Systematics. Elsevier Academic Press, San Diego.

Souza, B.M. \& Esteves, G.L. 2002. Tiliaceae. In: M.G.L. Wanderley, G.L. Shepherd \& A.M. Giulietti (eds.). Flora Fanerogâmica do Estado de São Paulo. Instituto de Botânica, São Paulo, v. 2, pp. 331-342.

Thiers, B. 2019. Index Herbariorum: A global directory of publish herbaria and associated staff. New York Botanical Garden's Virtual Herbarium. Disponível em http//sweetgum.nybg.org/ih (acesso em 29-I-2019).

Tschá, M.C., Sales, M.F. \& Esteves, G.L. 2002. Tiliaceae Juss. no estado de Pernambuco, Brasil. Hoehnea 29: 1-18. 